\title{
Landscape and microhabitat features determine small mammal abundance in forest patches in agricultural landscapes
}

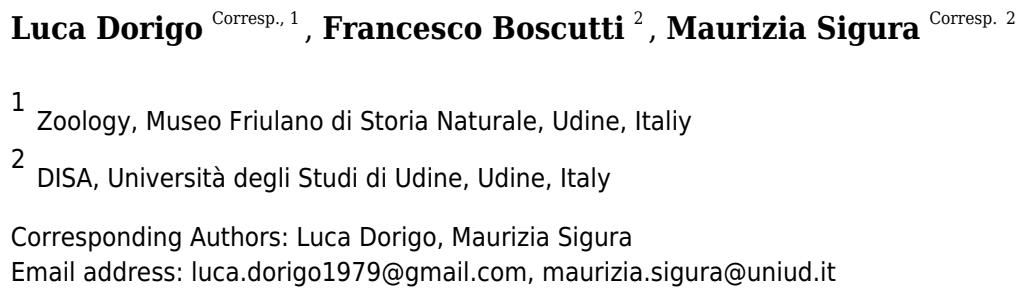

Intensification of agricultural landscapes represent a major threat for biodiversity conservation also affecting several ecosystem services. The natural and semi-natural remnants, available in the agricultural matrix, represent important sites for small mammals and rodents, which are fundamental for sustaining various ecosystem functions and trophic chains. We studied the populations of two small mammals (Apodemus agrarius, $A$. sylvaticus), to evaluate the effects of landscape and habitat features on species abundance along a gradient of agricultural landscape intensification. The study was performed in Friuli Venezia Giulia (north-eastern Italy) during 19 months, in 19 wood remnants. Species abundance was determined using Capture-Mark-Recapture (CMR) techniques. In the same plots, main ecological parameters of the habitat (at microhabitat and patch scale) and landscape were considered. Abundance of $A$. agrarius increased in landscapes with high extent of permanent crops (i.e. orchards and poplar plantations) and low content of undecomposed litter in the wood understory. Instead, A. sylvaticus, a more generalist species, showed an opposite, albeit less strong, relationship with the same variables. Both species were not affected by any landscape structural feature (e.g. patch shape, isolation). Our findings showed that microhabitat features and landscape composition rather than wood and landscape structure affect populations' abundance and species interaction. The opposite response of the two study species was probably because of their specific ecological requirements. In this light, conservation management of agricultural landscapes should consider the ecological needs of species at both landscape and habitat levels, by rebalancing composition patterns in the context of ecological intensification, and promoting a sustainable forest patches management. 
1 Landscape and microhabitat features determine small mammal abundance in

2 forest patches in agricultural landscapes

3

4

5 Luca Dorigo $^{\mathrm{a}^{*}}$, Francesco Boscutti ${ }^{\mathrm{b}}$, Maurizia Sigura $\mathrm{b}^{*}$

6

7 a Museo Friulano di Storia Naturale, Udine, Italy

8 b Università degli Studi di Udine (DISA), Udine, Italy

9

$10 *$ Corresponding author:

11 Luca Dorigo

12 via Sabbadini 22, 33100 Udine, Italy

13 E-mail address: luca.dorigo1979@gmail.com

14 Maurizia Sigura

15 via delle Scienze 206, 33100 Udine, Italy

16 E-mail address: maurizia.sigura@uniud.it

17 


\section{Abstract}

27 Intensification of agricultural landscapes represent a major threat to biodiversity conservation also affecting several ecosystem services. The natural and semi-natural remnants, available in the agricultural matrix, represent important sites for small mammals and rodents, which are fundamental for sustaining various ecosystem functions and trophic chains. We studied the populations of two small mammals (Apodemus agrarius, A. sylvaticus), to evaluate the effects of landscape and habitat features on species abundance along a gradient of agricultural landscape intensification. The study was performed in Friuli Venezia Giulia (north-eastern Italy) for 19 months, in 19 wood remnants. Species abundance was determined using Capture-MarkRecapture (CMR) techniques. In the same plots, the main ecological parameters of the habitat (at microhabitat and patch scale) and landscape were considered. Abundance of A. agrarius increased in landscapes with lots of permanent crops (i.e., orchards and poplar plantations) and low content of undecomposed litter in the wood understory. Instead, A. sylvaticus, a more generalist species, showed an opposite, albeit less strong, relationship with the same variables. Both species were not affected by any landscape structural feature (e.g., patch shape and isolation). Our findings showed that microhabitat features and landscape composition rather than wood and landscape structure affect populations' abundance and species interaction. The opposite response of the two study species was probably because of their specific ecological requirements. In this light, conservation management of agricultural landscapes should consider the ecological needs of species at both landscape and habitat levels, by rebalancing composition patterns in the context of ecological intensification and promoting a sustainable forest patches management. 


\section{Keywords}

50 Agricultural landscape, small mammals, Apodemus, wood structure, landscape pattern,

51 microhabitat features.

\section{Introduction}

54 Land use change, intensification of agricultural practices, fragmentation of natural habitats and 55 the consequent alteration of biological communities lead to a widespread decline in farmland

56 biodiversity, measured across many different taxa (Batáry et al. 2020; Benton et al. 2003; Geiger

57 et al. 2010; Kleijn et al. 2011). In agricultural landscapes, a principal task for the conservation of

58 farmland biodiversity and related ecosystem services is the understanding of the relationships

59 between habitat features, habitat pattern and species population dynamics (Fahrig 2007; Le Roux

60 et al. 2008; Tscharntke et al. 2005). The need to preserve and enhance agricultural landscape

61 diversity via management of non-crop habitats (i.e., field margins, woodlots, hedgerows, and

62 perennial grasslands) to support high levels of agricultural biodiversity is largely confirmed

63 (Carvell et al. 2011; Dainese et al. 2015, 2016; De Simone et al. 2017).

64 Small forest patches may deliver several important ecosystem services to human society, but

65 they receive little attention compared to large forest ecosystems. In particular, small forest

66 patches represent central elements in the long-standing conflict between the need of agriculture

67 productions and biological conservation (Biber et al. 2015; Benayas 2008).

68 In a recent review Decocq et al. (2016) focused on the ecosystem services delivered by small

69 forest patches of agricultural landscape highlighting their potential to support biodiversity both in

70 situ (forested patch) and in the proximity area enhancing landscape connectivity. Here, patch

71 structural features ( $\mathrm{pH}$ of soil, nutrient availability, light) and habitat configurations patterns (i.e., 
72 forest patch size, patch isolation) were defined as drivers for internal species richness and

73 community composition.

74 Rodents and other small mammals are rarely target of conservation studies since they are often

75 considered as pest or menace to production (Brown et al. 2007; Butet et al. 2006; Dickman 1999;

76 Putman 1989), thus associated with negative impacts on human activities (Capizzi et al. 2014).

77 However, small mammals are pivotal for important ecosystem functions (Dickman 1999). They

78 contribute to soil aeration (Laundre and Reynolds 1993) and play an important role as consumers

79 of weeds and insects (Bricker et al. 2010; Gliwicz and Taylor 2002). Small mammals are crucial

80 for diaspore dispersal of plants (Bogdziewicz et al. 2020; Steele et al. 2005) and fungi (Capizzi

81 and Santini 2007; Sieg 1987). In several ecosystems they sustain food chains, representing the

82 main prey biomass for several predator groups, such as birds, reptiles, and mammals (Martin

83 1994; Salamolard et al. 2000; Šálek et al. 2010) and greatly contribute to the overall complexity

84 of foodwebs (Butet and Leroux 2001; Korpimaki and Norrdahl 1991). For instance, low prey

85 densities have been proved to affect raptor nesting densities in agricultural landscapes (see e.g.,

86 Michel et al. 2006).

87 The populations of some small mammal species have experienced a decline, sometimes drastic,

88 probably because of agriculture intensification (Macdonald et al. 2007; Palmeirim et al. 2020),

89 acting at both landscape and patch levels. In particular, the intensification of agricultural

90 landscapes has been shown to decrease the density of rare and stenoecious species in favor of

91 generalist ones (Burel et al. 2004; Gentili et al. 2014; Millàn de la Peña et al. 2003), provoking

92 idiosyncratic responses. For example, Silva et al. (2005) and Serafini et al. (2019) found that

93 both structural complexity (e.g., coverage and shape of forest patches) and landscape

94 heterogeneity (e.g., different land-use covers) promoted small mammal species diversity. On the 
95 other hand, Michel et al. (2006) demonstrated that, in areas where land-uses are relatively

96 homogeneous (less landscape heterogeneity), species evenness but not species richness was

97 negatively affected by the increasing of agricultural land-use intensification. At the patch scale,

98 forest-floor characteristics, presence of coarse woody debris, understory vegetation, canopy

99 composition (Carey and Harrington 2001), forest age, vegetation complexity (Pearce and Venier

100 2005), presence of deadwood (logs and rotten trunks) and litter structure (Cox et al. 2000;

101 Kemper and Bell 1985; Marsh and Harris 2000; Simonetti 1989; Szymañski et al. 2020; Yahner

102 1986) can also influence small mammal occurrence. A high microhabitat complexity through

103 high shrub diversity, high vegetation cover and low percentage of ground covered by bare-soil

104 are known to increase overall small mammal abundance and species richness (Gelling et al.

105 2007, Silva and Prince 2008; Szymañski et al. 2020).

106 Most of the previous studies evidenced strong effect of environmental drivers on small mammal.

107 Nonetheless, comprehensive assessments at multiple ecological scales are still scarce and focus

108 on species autecology. In this light, comparing species with different behavior (i.e. generalist vs

109 specialist) should be encouraged to get new insights into future agricultural landscape

110 management.

111 In this study we investigated the effects of environmental features on small mammal abundance

112 paying particular attention to forest specialists and habitat generalist species. We considered

113 three different ecological scales: microhabitat, habitat (patch), and landscape. In particular, we

114 tested the effects of landscape composition and configuration, forest structure and forest ground

115 features on two small mammal species (i.e., Apodemus sylvaticus, and A. agrarius) in remnants

116 of wood vegetation along an intensification gradient of agricultural land use. These species were 
117 chosen as they represent typical species of lowland woodlots, very common in the study area

118 (Dorigo, 2018) and can easily be captured with live-capture systems.

119 Specifically, we ask two questions: (1) What are the relative and independent effects of

120 heterogeneity of landscape elements, composition and configuration on small mammals

121 abundance in woodlots within agricultural landscapes? (2) Does the effect of these mosaic

122 properties differ between species with different ecological needs?

123 We expected to find a strong interplay between landscape composition and habitat features in

124 determining small mammals species distribution and abundance. In particular, we expected to

125 find contrasting responses between the species considered, hypothesizing that the generalist $A$.

126 sylvaticus could be more affected by landscape composition and configuration rather than local

127 forest characteristics.

128

129 2. Materials and methods

130

\section{$131 \quad$ 2.1. Study area, species and sampling design}

132 The study was conducted in the agricultural landscape of Friuli Venezia Giulia region, North-

133 East Italy $\left(45^{\circ} 56^{\prime} \mathrm{N}, 12^{\circ} 47^{\prime} \mathrm{E}\right.$ ), an extensive lowland area (from 20 to $36 \mathrm{~m}$ a.s.1.) of alluvial

134 deposits (Fontana, 2006). In the study area, a matrix of intensively-farmed arable fields of annual

135 crops (winter cereals, Zea mays, and Glycine max) and permanent plantation (poplars and

136 orchards) is discontinued by small hedgerows and woodlots.

137 Two small mammals species were considered. Apodemus sylvaticus (Linnaeus 1758) is a habitat

138 generalist and opportunist species with high dispersal ability; it can occupy all woodlots and

139 hedgerows, moving frequently between patches (Bauchau and Le Boulengé 1991; 
140 Fuentes-Montemayor et al. 2020). Its main diet includes seeds, fruits, green parts of plants and

141 fungi, but the animal component can be substantial only in some periods of the year (Canova and

142 Fasola 1993; Hansson 1985). Apodemus agrarius (Pallas 1771) is a hygrophilous species which

143 feeds on high-caloric food of animal and plant origins (Babińska-Werka 1981). Its diet is quite

144 varied and includes a wide range of invertebrates and plants (Babińska-Werka and Garbarczyk

145 1981), in form of seeds and green parts (Babińska-Werka 1981). In northern Italy, the species

146 usually occurs at low altitudes, in the edges of mesophilous woods and in forest river banks

147 (Zulian 1987).

148 Sampling sites were 19 remnant woodlots not harvested in the past three years, characterized by

149 medium-wet soils and smaller than 8 ha in size. The patches were selected along a gradient of

150 landscape intensification ranging from $5 \%$ to $33 \%$ of semi-natural habitats with a $500 \mathrm{~m}$ buffer

151 around each patch. The buffer size was established in agreement with the mobility of the most

152 abundant small mammal species found (Liro and Szacki 1987). The same distance was assumed

153 to consider sampling patches as independent from each other. Patches with less than $500 \mathrm{~m}$

154 distance from each others were considered only if they are separated by barriers (i.e.

155 watercourses more than $5 \mathrm{~m}$ wide and one meter depth).

\section{2.2. Data collection}

\section{2.2.1. Small mammal sampling}

159 As trapping method we used Sherman traps (LFA type: cm 8 x 9 x 24. H.B. Sherman Traps()).

160 This method of capture tends to be selective because it traps mostly small mammals weighing at

161 least 5 grams like Murids (i.e., Apodemus, Mus, and Rattus in the study area) (Caceres et al.

162 2011; Umetsu et al. 2006). It, therefore, precluded the capture of smaller insectivorous mammals. 
163 Within each sampling patch, 10 Sherman traps, spaced $10 \mathrm{~m}$ from each other, were placed along

164 a $100 \mathrm{~m}$ line-transect. The traps were baited with pieces of fresh apple and sunflower seeds

165 (Tallmon and Mills 1994), to ensure the survival of trapped animals and were activated for four

166 consecutive nights. Samplings during periods with excessive rainfall were excluded to avoid an

167 excessive mortality of animals. To improve the control of temperature, each trap was lined on the

168 bottom with dry plant material particularly important during the cold season.

169 In all areas (sites), four sampling sessions were repeated from April, 2013 to October 2014.

170 Traps were checked once a day in the morning. Animals were trapped using the CMR (Catch-

171 Mark-Recapture) method. Each individual was marked with an ear tag (Opivi Brand $®)$, and its

172 species, body mass, sex and age (juvenile, sub-adult and adult age classes) were recorded. The

173 animals were released again at the same place where they were trapped. Trapping activities were

174 authorized by the Italian Institute for Environmental Protection and Research (ISPRA) (Aut.

175 PG/Ir Rif. Int. 26358-28967/2013) and by the Friuli Venezia Giulia region (Aut. Prot.

176 SCPA/12.5/17552-2013).

177

178 2.2.2. Microhabitat structure features

179 Microhabitat features were measured in sub-sample areas placed along the line transects with

180 live traps (according to Amori et al. 2015). Around each trap, the ground cover was assessed

181 within a buffer of $5 \mathrm{~m}$. In particular, the cover percentage of herbaceous layer, rocky soil, bare

182 ground, leaf litter and coarse woody debris (considering even small deposits of material also with

183 diameter $<3 \mathrm{~cm}$ ) were visually estimated as percentage cover (Amori et al. 2015).

184 Finally, litter composition was evaluated, estimating the percentage of the categories: non-

185 decomposed litter (whole leaves); partially decomposed litter (leaves partially degraded but leaf 
186 structure still recognizable); degraded litter (leaf structure not recognizable) in the litter stratum.

187 This was carried out by two operators simultaneously around each trap, and the results were 188 averaged.

189

\section{$190 \quad$ 2.2.3. Wood structure features}

191 At patch scale the presence of deadwood, understory stratification, tree diameter, woody and 192 understory species and the presence of non-native tree and shrub species were assessed.

\section{Deadwood}

194 Deadwood was measured in spring 2015 following mainly the protocol of Bianchi et al. (2013).

195 We measured with a caliper the diameters of all the logs (e.g., stems, branches) (if $>3 \mathrm{~cm})$.

196 Length of the sample and decomposition state were also recoded. We used fixed area sampling

197 (FAS) method (Harmon and Sexton 1996), considered more reliable than other methods,

198 especially with high amount of necromass composed of small fragments (Bianchi et al. 2013;

199 Warren and Olsen 1964). Measures of deadwood were carried out in the central part of the forest

200 along the transect used with traps for small mammals, around the traps 2,5 and 8 of each

201 transect.

202 Around selected traps a $5 \mathrm{~m}$ radius area $\left(78.5 \mathrm{~m}^{2}\right)$ was surveyed. We opted for a lower threshold

203 than indicated by Bianchi et al. (2013), since the studied woodlots are of recent origin and

204 deadwood is often composed of small size logs. Branches and woody fragments of diameters less

205 than $3 \mathrm{~cm}$ were not considered in this protocol but were still evaluated as potential microhabitats

206 (see Microhabitat, above). Each log (e.g., stems, branches) of diameter $>3 \mathrm{~cm}$ was measured

207 (length, major radius, minor radius) and referred to one of the three categories of the following

208 scale: (i) standing deadwood, newly formed deadwood, with logs standing (Marsh and Harris 
209 2000); (ii) ground deadwood, deadwood on the ground; (iii) rotten deadwood, deadwood with

210 spongy woody tissue and soaked with water.

211 The deadwood volume was calculated using the following formula (1):

212

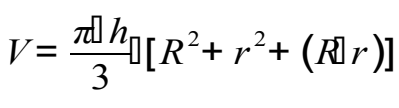

213 where $\mathrm{V}$ is the volume, $\mathrm{h}$ is the height/length, $\mathrm{R}$ is the major radius, $\mathrm{r}$ is the minor radius

214 (Harmon and Sexton, 1996). The total values of the deadwood, for each stage, were then

215 averaged between the three FAS considered for each sampling station.

216 Understory shrub density

217 We measured the renewal capacity and the vertical stratification of the understory layer of the 218 studied woods. In particular, we identified, along the transect used with the traps for the small 219 mammals samplings (around the trap 2, 5 and 8 of each transect), circular areas of $2 \mathrm{~m}$ radii $220\left(6.28 \mathrm{~m}^{2}\right)$. Within each area, all woody plants with diameter of less than $7.5 \mathrm{~cm}$ have been

221 recorded, indicating the species, and measuring the stem diameter at ground level.

222 Trees density and diameter

223 In the center of the transect (trap 5), we placed a 10x10 m plot, inside of which we noted the 224 number of woody plants with more than $7.5 \mathrm{~cm}$ in diameter. For each plant we reported the 225 species and the diameter at breast height (D.B.H). All data were finally pooled as the average 226 diameter of each plot, considering their standard deviation as a proxy of plot variability.

227 Presence of alien species

228 We verified the presence of non-native arboreal plants within the $10 \times 10 \mathrm{~m}$ plots (see above:

229 Trees density and diameter) as well as the presence and the number of non-native shrubby plants 230 inside the $2 \mathrm{~m}$ radii plots (see above: Understory shrub density). 


\section{2.2.4. Landscape structure features}

233 Land use was mapped in two concentric buffers, respectively of $500 \mathrm{~m}\left(0.785 \mathrm{~km}^{2}\right)$ and $250 \mathrm{~m}$

$234\left(0.196 \mathrm{~km}^{2}\right)$ radii, around the 19 surveyed remnant woodlots. Land use types were mapped using

235 aerial images of the study area (year 2014) in a Geographic Information System (GIS) open

236 source environment (QGIS). Mapped land use classes were (1) arable lands, i.e., annual crops;

237 (2) permanent crops, i.e., orchards, vineyards and poplars; (3) set aside, i.e., fallow lands,

238 uncultivated areas with herbs and shrub cover; (4) woods, i.e., hedgerows and woodlots; (5)

239 settlements, i.e., urban areas, industrial areas and isolated buildings. Rivers and roads were not

240 considered as polygons but measured as linear elements (length).

241 Landscape pattern was analyzed by means of landscape metrics considering features at both

242 patch and landscape scales (composition and configuration). For this purpose, selected variables

243 were: woodlot surface area; woodlot perimeter; woodlot area to perimeter ratio $(\mathrm{k}=\mathrm{a} / \mathrm{p})$; Patch

244 Shape Index $\left(P S I=\frac{\text { Perimeter }}{\sqrt{2 \sqrt{2 ! \text { Area }}}}\right)$; Mean proximity index for all patches in the landscape (MPI);

245 mean proximity index for patches comprising the wood class (MPI_Wood); Mean nearest-

246 neighbor distance for patches comprising the wood class (MNN); Interspersion and juxtaposition

247 index for patches comprising the wood class (IJI); Total number of wood patches in the

248 landscape (NumP); Mean patch size for patches comprising the wood class (MPS); Total edge

249 for patches comprising the wood class (TE); Percent of landscape occupied by each patch type in

250 the landscape (PLAND); Modified Simpson's diversity index based on Pielou's (1975)

251 modification of Simpson's diversity index (MSIDI). Landscape structure analyses were

252 performed using the Fragstat software (McGarigal et al., 2012).

253

254 2.3. Data analyses

Peer] reviewing PDF | (2021:04:60235:2:0:NEW 16 Aug 2021) 
255 Low re-capture probability, and thus unreliable estimates of abundance, did not allowed us to use

256 estimates of abundance taken from capture-recapture models, therefore an abundance index was

257 used. Population abundance was calculated by the relative abundance index (RAI), used as a

258 proxy measure of population density (Cagnin et al. 1998; Klaa et al. 2005; Ouin et al. 2000)

259 according to the formula (2).

260

$R A I=\frac{N s}{n s} \llbracket t s \square 100$

261

262 where $s$ is the sampling site, $N$ is the number of individuals of each species, $n$ is the number of

263 nights that a trap is open for, and $t$ is the number of active traps.

264 For each site, 40 environmental variables were measured, grouped in microhabitat structure (8),

265 wood structure (13), landscape composition (6) and landscape configuration (13). All analyses

266 were performed using R statistical software (R Core Team 2021).

267 All the variables were initially analyzed and selected to cope (multi-) collinearity and to obtain

268 more parsimonious models (Faraway 2005). Variable collinearity was assessed through Principal

269 Component Analysis (PCA) and Pearson correlation (Pearson's $r<0.6$ ), using the 'car' package

270 (Fox and Weisberg 2011). After this selection, 19 variables were kept as environmental

271 predictors, divided in four groups: (i) microhabitat structure, i.e., litter cover percentage, coarse

272 woody debris percentage, bare ground percentage, and undecomposed litter percentage; (ii)

273 wood structure, i.e., tree species number, tree DBH, tree density, shrub density, number of shrub

274 species, total deadwood, and rotten deadwood; (iii) landscape composition, i.e., percentage of

275 arable land, woods, permanent crops, settlements, and set aside; (iv) landscape configuration,

276 i.e., area/perimeter ratio, PSI, and MPI_Wood. 
277 Multi-model inference (MMI) within an information theoretic framework was used to evaluate

278 the influence of environmental variables on the abundance of Apodemus agrarius and $A$.

279 sylvaticus, at the different scale (Burnham and Anderson 2002). This technique compares the fit

280 of all possible models (including the null model) obtained by the combination of the variables

281 with the "dredge" function in the MuMIn package (Bartoń, 2015) of the R software. We used

282 Akaike's information criterion (AIC) (Akaike 1973) to choose the best fitting model. AIC

283 measures the relative quality of a model dealing with the trade-off between the complexity of the

284 model and the goodness of fit. The best fit is indicated by the lowest AIC value (AIC MIN). In a

285 set of models each model (i) can be ranked using its difference in AIC score to the best-fitting

286 model $(\triangle \mathrm{AIC} i=\mathrm{AIC} i-\mathrm{AIC} i \mathrm{MIN})$. A model in the set can be considered plausible if its $\triangle \mathrm{AIC}$ is

287 below 2 (Burnham and Anderson 2002). We also derived the Akaike's model weight ( $\left.\mathrm{w}_{i}\right)$ which

288 is the probability that the model $(i)$ is the best-fitting model if data were collected again under

289 identical circumstances (Burnham and Anderson 2002). We also calculated the relative

290 importance of the variables using Akaike's model weight.

291 Linear mixed models (LMMs) were used to estimate model parameters as model residuals

292 approximated a normal distribution. Models included population abundance as response variable

293 and species, environmental variables, and their interactions as fixed effects. The transect ID was

294 included as random effect. Because of the low number of real replicates, the four groups of

295 variables linked with the three scale levels (microhabitat, habitat, landscape composition +

296 configuration) were modeled separately. An overall model was performed using only the

297 variables which had a significant averaged coefficient $(\mathrm{p}<0.05)$ and a high Relative Variable

298 Importance (RVI) value (RVI $>0.7)$. LMMs were conducted for each response variable separately

299 using both a linear model with and without including a quadratic term to account for a possible 
300 non-linear relationship. The multi-model inference based on AIC was executed with the

301 'MuMIn' package (Bartoń 2016). The linear mixed models were applied using the "nlme"

302 package (Pinheiro et al. 2017). Model goodness-of-fit was further tested using diagnostic plots of

303 residuals and goodness indices (Faraway 2005; Zuur et al. 2009).

304

305 3. Results

306 In all sampling sessions 868 captures were recorded, of which $36.5 \%$ were recaptured

307 individuals. The total capture effort was 3024 trap-nights, with a capture index $(\mathrm{Ic}=\mathrm{N} \times 100$

308 catch / trap-nights) of 28.7. Among the catches, 55.3\% was represented by A. agrarius, $40.1 \%$ of

309 A. sylvaticus, $4.1 \%$ by Rattus norvegicus and the remaining $0.5 \%$ by $R$. rattus, Microtus arvalis

310 and Crocidura suaveolens.

311 Apodemus sylvaticus was caught in all sampling sites while A. agrarius occured in 16 sites and,

312 together, these species represented about $95 \%$ of the individuals caught. Both rodent species

313 were caught in all sampling sessions. For all the investigated scales the null models showed a

314 low weight (weight $<0.001$ ) and were not considerable as plausible (delta AIC $>12$ ).

315

\section{3.1 Microhabitat structure}

317 For microhabitat structure, the multi-model inference showed that eight models were supported

318 (Table 1). The models included the percentage of deadwood, ground cover of bare soil,

319 percentage of undecomposed litter, species, and their interaction. The most important variable

320 was the percentage of undecomposed litter and its interaction with species $(R V I>0.70 ; p=0.05)$.

321 Albeit not significant, presence of deadwood and ground cover of bare soil were also important

$322(\mathrm{RVI}=0.71$ and 0.68 , respectively), whereas their interactions with species were negligible. In 
323 general, small mammals abundance decreased as undecomposed litter increased. Models

324 explained between 27 and $29 \%$ of the total variation in small mammal abundance.

325

\section{$326 \quad 3.2$ Wood structure}

327 For the group of variables describing the wood structure, the multi-model inference showed that

328 there were seven plausible models, which included tree density, $\mathrm{DBH}$, tree species richness,

329 shrub richness, small mammal species and their interactions (Table 2). Among these variables,

330 tree density, number of tree species (and its interaction), number of shrub species (and its

331 interaction) showed a high relative importance (RVI $>0.7)$, albeit none of them was significant.

332 The models explained between 20 and $28 \%$ of the total variation in small mammal abundance.

333

\section{$334 \quad 3.3$ Landscape configuration}

335 The analysis was conducted for both $500 \mathrm{~m}$ and $250 \mathrm{~m}$.

336 Using landscape configuration variables in $250 \mathrm{~m}$ buffers, three models were supported (Table

337 3), which included the following variables: area/perimeter ratio, PSI, species. The most

338 important, albeit not statistically significant, was Patch Shape Index and its interaction with

339 species (RVI>0.91). Models explained between 6 and $11 \%$ of the total variation in small

340 mammals abundance.

341 Considering the same descriptors within $500 \mathrm{~m}$ buffers, seven plausible models were obtained,

342 including the variables: area/perimeter ratio, PSI, MSI, species and their interactions with the

343 variables (Table 4). Also in this case, no variable showed a high RVI value (>0.7), with the

344 exception of the PSI (and its interaction with the species). The most important, albeit not 
345 statistically significant, was PSI and its interaction with species (RVI $>0.91)$. Models explained

346 between 6 and $26 \%$ of the total variation in small mammals abundance.

347

$348 \quad 3.4$ Landscape composition

349 The analysis was conducted for both $500 \mathrm{~m}$ and $250 \mathrm{~m}$ radius buffers.

350 Using landscape composition variables in $250 \mathrm{~m}$ buffers, four models were supported (Table 5).

351 These models included crop percentage, permanent crop percentage, and settlement percentage.

352 The most important variable was the percentage of permanent crops and its interaction with

353 species (RVI $>0.70 ; p=0.05)$. Settlement percentage was also important among models

354 (RVI=0.72), but not statistically significant.

355 Considering landscape composition variables within $500 \mathrm{~m}$ buffers, three models were supported

356 (Table 6). These models included crop percentage, permanent crop percentage, and settlement

357 percentage. The most important variable was the percentage of permanent crops and its

358 interaction with species $(\mathrm{RVI}>0.89 ; \mathrm{p}=0.05)$.

359

$360 \quad 3.5$ Overall model

361 The multi-model inference applied to the selected variables from each environment structural

362 level (overall model) showed one supported model both in $250 \mathrm{~m}$ and $500 \mathrm{~m}$ buffers (Table 7, 8).

363 The models confirmed the importance of the extension of permanent crops and the

364 undecomposed litter layer, highlighting a significant interaction of the study species with the

365 variables $(\mathrm{p}<0.001 ; \mathrm{RVI}>0.7)$. In particular, where the landscape had a higher percentage of

366 permanent crops, the abundance of $A$. agrarius increased, whereas the abundance of $A$. sylvaticus

367 decreased (Fig. 1a). Instead, an increase of undecomposed litter favors A. sylvaticus, decreasing 
368 the abundance of A. agrarius (Fig. 1b). The models including variables within the 250 and $500 \mathrm{~m}$

369 buffers explained respectively 56 and $51 \%$ of the total variation in small mammals abundance.

370

371 4. Discussion

372 Our findings shed new light on the interplay between different ecological scales in determining

373 small mammals abundance and distribution. We found species with different ecological niches to

374 differ significantly in landscape and habitat features, suggesting the occurrence of alternative

375 strategies for species coexisting in fragmented forest patches in agricultural landscapes.

376 Considering the contribution of each variable group and their selection, we found both landscape

377 composition and microhabitat features to significantly affect species abundance, with contrasting

378 species responses. On the contrary, wood structure did not directly influence the abundance of

379 the two studied species, not confirming previous studies evidencing significant relationships

380 between abundance of small mammal forest species and forest tree density (Capizzi and Santini

381 2007) and size (Capizzi et al. 2003). Albeit not significant, our results also highlighted positive

382 relationships between small mammal abundance and tree density, as well as number of tree

383 species and number of shrub species, that could be interpreted as direct relationship with the

384 complexity of the ecological niche. Several studies reported a strong relationship between

385 deadwood abundance and the presence of small mammals. In fact, deadwood represents a source

386 of potential shelters and hosts large invertebrate communities which are potential sources of food

387 (Amori et al. 2015; Bellocq and Smith 1997; Bowman et al. 2000; Harmon et al. 1986; Kemper

388 and Bell 1985; McCay 2000; Miller and Getz 1977; Szymañski et al. 2020; Tallmon and Mills

389 1994; Yahner 1986). Several studies also indicate that the decay stage may be important in

390 habitat selection of small mammals (Bowman et al. 2000; McCay 2000). Availability of 
391 understory cover is also a key condition for small mammals (Barry et al. 1984; Bellocq and

392 Smith 1997; Carey and Harrington 2001; Cox et al. 2000; Marsh and Harris 2000; Simonetti

393 1989). Probably its importance is connected with food availability and the related possibility to

394 reduce either the areas of predation (Bellocq and Smith 1997; Miller and Getz 1977; Simonetti

395 1989) or the competition, by expanding the available space (Montgomery 1980). Regarding

396 microhabitat structure, the bare soil cover, presence of deadwood and litter structure are known

397 to affect small mammal populations (Amori et al. 2015; Cox et al. 2000; Denny et al. 2021;

398 Kemper and Bell 1985; Marsh and Harris 2000; Simonetti 1989; Yahner 1986). Our results

399 confirmed these findings, but highlighted the pivotal role of the litter decomposition stage. Litter

400 decomposition rate is driven by environmental conditions, chemical composition of soil and

401 intensity of soil organism activity (Aerts 1997; Harmon et al. 1986).

402 The speed and degree of degradation of leaves depends mainly on the species of tree (He et al.

403 2019; Mathews and Kowalczewski 1969; Nykvist 1962) and other environmental variables such

404 as temperature and humidity. In addition, the presence of large invertebrates such as earthworm,

405 millipedes and other taxa is also relevant, enhancing the degradation of organic matter (Bocock

406 1964; Mathews and Kowalczewski 1969; Tresch et al. 2019). The dynamics of the soil

407 degradation process is connected to invertebrate biodiversity: well developed temperate

408 woodland soils can host up to a hundred species of animals (Anderson 1975; Tresch et al. 2019).

409 Moreover, leaf litter quality affects numerous trophic levels such as insects, other invertebrates

410 (Koivula et al. 1999; Sabo et al. 2005) and small mammals (Canova and Fasola 1991; Hansson

411 1978; Kaminski et al. 2007). Litter cover affects the use of habitat by black rats (Cox et al.

412 2000), which spend most of the time foraging on the ground, probably obtaining food from the

413 litter (Cox et al. 2000). 
414 A dense litter cover would produce suitable mesic conditions in soil and litter ensuring

415 appropriate microenvironments for litter-dwelling arthropods used as food (Yahner 1986). Wood

416 mice catch and find invertebrate prey, which are an important source of food, under litter cover

417 (Piper et al. 2014). The microclimate conditions of the litter can influence movements of small

418 mammals, whom sounds are more difficult to hear in moist than in dry litter, influencing

419 predation (Vickery and Bider 1981). Predation risk is considered one of the most important

420 factors determining selection of microhabitat in small mammals (Bellocq and Smith 1997;

421 Fragoso et al. 2020; Simonetti 1989).

422 Despite this evidence, we found a different interaction of the two considered species with the 423 environment conditions. In fact, abundance of $A$. agrarius was inversely related with the 424 percentage of undecomposed litter, while the opposite trend was observed in A. sylvaticus.

425 Probably A. agrarius is more dependent on litter quality because it generally avoids xeric 426 conditions, as reported by Yahner (1986) for other species in relation to the moisture of the 427 habitat. This species is known to prefer habitats with dense soil cover and it usually moves 428 through the litter stratum because of its fossorial behaviour (Kuncová and Frynta 2009), probably 429 to escape predators (Orlandi and Paolucci 2004).

430 On the contrary, A. sylvaticus occurs in both woody and in open habitats (Heroldová et al. 2007) 431 avoiding cut crops or cut set aside (Tattersall et al. 2001) and bare soil (Tew et al. 2000), 432 showing this species is poorly influenced by the structure of litter, in disagreement with what is 433 reported in other studies (e.g., Balestrieri et al. 2017).

434 Moreover, A. sylvaticus is apparently not affected by wood characteristics probably because this 435 ubiquitous species prefers the diversity of the complex mosaic created by agricultural landscape 436 rather than the continuous forest habitat (Geuse et al. 1985; Kozakiewicz et al. 1999). 
437 It is well known that composition of landscape can influence the population dynamics of small

438 mammals (Fischer and Schoder 2014; Silva et al. 2005). Our results confirmed this evidence

439 pointing out the positive role of some non-natural habitats (i.e., permanent crops) in agreement

440 with what was found in other studies (Fitzgibbon 1997; Macdonald et al. 2007; Tattersall et al.

441 1999; Vieira et al. 2009). Even though some studies showed small mammal abundances to be

442 related with landscape structure (Fischer et al. 2011; Kozakiewicz et al. 1999; Macdonald et al.

443 2007; Van Apeldoorn et al. 1992; Vieira et al. 2009), in our study, no significant relationship

444 emerged considering landscape configuration. We observed a positive relationship between the

445 abundance of $A$. agrarius and the presence of permanent crops, despite the percentage of natural

446 woods was relatively low in the studied area (ca. $8 \%$ on average). This result suggests that

447 permanent woody crops, such as poplars and orchards, may be important habitats for the study

448 species, especially if placed in the surroundings of woodlots, offering canopy cover and in some

449 cases a dense leaf litter. On the contrary, we did not observe such strong relation for $A$.

450 sylvaticus, which seems less influenced by the presence of permanent crops in the landscape but

451 with a negative relationship. It seems that $A$. sylvaticus in Mediterranean areas uses mostly nests

452 positioned far away from orchards, probably to avoid predation (Rosalino et al. 2011), although

453 other studies show that the species is quite common in poplar plantations (Balestrieri et al. 2017)

454 and orchards (Dickman and Doncaster 1987).

455 The differences found for the two species could be linked to their ecological requirements.

456 Our results suggest that $A$. agrarius, a species connected to the presence of wood mosaic, uses

457 permanent plantations in highly modified landscapes probably as surrogate of forest habitats.

458 The abundance of this species was negatively related with the amount of arable land so that it 
459 becomes absent in very simplified landscapes (Fischer et al. 2011). Then, permanent crops could

460 become an important secondary habitat for this rodent in intensive agricultural landscapes.

461 A. sylvaticus, instead, has a broad ecological niche and can exploit many different habitats (Halle

462 1993; Michel et al. 2006), such as fallow lands (Heroldová et al. 2007; Macdonald et al. 2007)

463 and crops (see for instance Tattersall et al. 2001). This species has high dispersal abilities (Marsh

464 and Harris 2000) and is supposed to have higher abilities to navigate in crops (Sozio et al. 2013).

465 In cultivated landscapes, A. sylvaticus moves from hedgerows to crop fields according to seasons

466 (Ouin et al. 2000). At the time of the crop, wood mice massively overrun the fields and remain

467 there until the time of ploughing (Heroldová et al. 2007); during winter more mice are found in

468 field edges than in the center of fields, and when the crop are cut down they prefer hedgerows,

469 woodland edges (Macdonald et al. 2000; Tattersall et al. 2001), woods and fallow lands (Tew

470 and Macdonald 1993). This allowed them, to avoid predation, which can bring high rates of

471 mortality (Tew and Macdonald 1993). The wood mouse is therefore well represented in

472 intensified sites because it certainly benefits from landscape heterogeneity as it can find and

473 exploit many resources (Michel et al. 2006). As observed by Bellows et al. (2001) for other

474 rodent species, the lack of relations between the species and microhabitat characteristic is

475 probably because of its ability to exploit a variety of sources.

476 We did not observe significant relationships between species abundance and percentage of

477 settlements in the surroundings, within the considered buffers. This fact may be interpreted as the

478 low presence of urban areas, reduced in the study sites to a few scattered agglomerates of

479 buildings (ca $8.5 \%$ in a $500 \mathrm{~m}$ buffer).

480

481 5. Conclusions 
482 Our findings revealed that, in the study areas, landscape composition rather than landscape

483 configuration significantly affect small mammals species in the considered agricultural

484 landscapes, which, along with microhabitat features and species interaction, drives species

485 abundance.

486 Our results showed that composition of agricultural landscapes is not perceived by all species in

487 the same way. Species respond to each ecological scale in relation to their own ecological

488 requirements, spatial behaviors, mobility, and dependency on habitat (Kozakiewicz et al. 1999;

489 Serafini et al. 2019). The maintenance of wider woodlots (or hedgerows) is, hence, necessary for

490 several aims, as: (i) protecting wildlife species with different ecological needs, (ii)

491 maintaining/enhancing habitat continuity, and (iii) avoiding structure simplification (Dondina et

492 al. 2016). Functional connectivity among habitat patches is proven to be one of the most

493 important factors affecting the presence of small mammals in urban areas (Fitzgibbon et al.

494 2007) but also matrix composition and management is fundamental since forest species can cross

495 agricultural surroundings (Mortelliti et al. 2013; Paise et al. 2020). Our results showed that the

496 presence of anthropogenic habitats in the landscape with plausible landscape connectivity

497 functions (such as permanent plantations) can also affect small mammals.

498 Studies have been carried on connectivity in the agricultural matrix, but the effect of forest

499 plantations on functional connectivity has received limited attention (Mortelliti et al. 2014).

500 Permanent tree crops, especially those aimed at producing woody biomass, have a negative

501 effect on biodiversity when they replace native forest vegetation (Brockerhoff et al. 2008;

502 Greene et al. 2019). It is already commonly believed that their effect may have less impact than

503 that of the agricultural matrix, since they are working as a semi-permeable barrier for organisms,

504 representing a compromise between maintaining the economic value of an area and reducing the 
505 effect of habitat fragmentation, increasing connectivity (Norton 1998; Brockerhoff et al. 2008;

506 Vanbeveren and Ceulemans 2019). Landscape connectivity as well as the habitat function, could

507 greatly increase if management rules are properly applied (Norton 1998; Lindenmayer et al.

508 2003; Zitzmann et al. 2021). This process may guarantee, for example, the permanence of mature

509 plants within plantations (Hanowski et al. 1997) or increase the shrub and herbaceous layers

510 (Moser et al. 2002), whose positive effect on small mammals is already known (Balestrieri et al.

511 2017). Even the understory cover and litter can promote biodiversity, if they are not completely

512 eliminated (Christian et al. 1997, 1998; Moser et al. 2002; Vanbeveren and Ceulemans 2019).

513 Our results showed that several properties of agricultural land mosaics had a strong influence on

514 small mammal abundance, and all of them are within the reach of farmers management. In this

515 study, we get new insight to support the concept of 'wildlife-friendly farming' (Fischer et al.

516 2014), which emphasizes the ecological interactions of farmed and unfarmed coexisting areas

517 and the improvement of natural and cultivated areas as strategy for an agricultural landscape

518 management aimed to increasing biodiversity. This would contribute to the implementation of

519 policy for the conservation of agricultural landscape at local and regional scales, and to farm

520 landscape design.

521

522 Ethical approval

523

524 All applicable international, national, and/or institutional guidelines for the care and use of 525 animals were followed.

526

527 Author's contribution 
529 All authors conceived the main idea. LD carried out measurements and data collection. LD and

530 FB analyzed the data. All authors discussed the results, contributed to the final manuscript and

531 have

532 approved the final version of the article.

533

534

535

536

537

538

539

540

541

542

543

544

545

546

547

548

549

\section{Acknowledgments}

We gratefully acknowledge Ivano Marcorin, Mattia Spessot, Costanza Uboni for their support during field activities. Thanks to Alessio Mortelliti, Sergio Muratore, Stefania Gentili and Laura Bonesi for helpful comments and precious recommendations.

\section{This research did not receive any specific grant from funding agencies in the public,} commercial, or not-for-profit sectors.

\section{References}

Aerts R (1997) Climate, Leaf Litter Chemistry and Leaf Litter Decomposition in Terrestrial Ecosystems: A Triangular Relationship. Oikos 79 (3): 439-449. https://doi.org/10.2307/3546886 Akaike H (1973) Information theory and an extension of the maximum likelihood principle. In: Csáki F, Petrov BN (Eds.) Proceedings of the 2nd International symposium on information theory. Akadémiai Kiadó, Budapest, Hungary, pp 267-281. 
550 Amori G, Luiselli L, Milana G, Casula P (2015) Small scale factors affect population size of the

551 wood mouse (Apodemus sylvaticus) in a mediterranean island (Sardinia). Revue d'Ecologie

552 (Terre et Vie) 70 (1): 58-69. http://hdl.handle.net/2042/56310

553 Anderson JM (1975) Succession, diversity and trophic relationships of some soil animals in 554 decomposing leaf litter. The Journal of Animal Ecology 44: 475-495.

555 https://doi.org/10.2307/3607

556 Babinska-Werka J (1981) Food of the striped Field Mouse in Different Types of Urban Green

557 Areas. Acta Theriologica 26 (17): 285-299.

558 Babińska-Werka J, Garbarczyk H (1981) Animal component of diet of striped field mouse under 559 urban conditions. Acta Theriologica 26: 301-318.

560 Balestrieri A, Remonti L, Morotti L, Saino N, Prigioni C, Guidali F (2017) Multilevel habitat 561 preference of Apodemus sylvaticus and Clethrionomys glareolus in an intensively cultivated 562 agricultural landscape. Ethology Ecology and Evolution 29 (1): 38-53.

563 http://dx.doi.org/10.1080/03949370.2015.1077893

564 Barry RE, Botje MA, Grantham LB (1984). Vertical stratification of Peromyscus leucopus and 565 Peromyscus maniculatus in southwestern Virginia. Journal of Mammalogy 65: 145-148.

566 https://doi.org/10.2307/1381217

567 Bartoń K (2016) MuMIn: multi-model inference. R package version, 1.15.6.

568 Bauchau V, Le Boulengé E (1991) Population biology of woodland rodents in a patchy

569 landscape. In: Le Berre M, Le Guelte L. (Eds.) Le Rongeur et l'Espace, Paris, pp 275-283.

570 Batáry P, Báldi A, Ekroos J, Gallé R, Grass I, Tscharntke T (2020) Biologia Futura: landscape

571 perspectives on farmland biodiversity conservation. Biologia Futura, 71, 9-18.

572 https://doi.org/10.1007/s42977-020-00015-7 
573 Bellocq MI, Smith SM (1997) Microhabitat preferences of Peromyscus maniculatus (Rodentia,

574 Cricetidae) in young pine plantations in the Canadian boreal forest. Ecología Austral 7: 57-64.

575 Bellows S, Pagels JF, Mitchell JC (2001). Macrohabitat and Microhabitat Affinities of Small

576 Mammals in a Fragmented Landscape on the Upper Coastal Plain of Virginia. The American

577 Midland Naturalist 146 (2): 345-360. https://doi.org/10.1674/0003-

$578 \quad$ 0031(2001)146[0345:MAMAOS]2.0.CO;2

579 Benayas JMR, Bullock JM, Newton AC (2008) Creating woodland islets to reconcile ecological

580 restoration, conservation, and agricultural land use. Frontiers in Ecology and the Environment

$581 \quad 6(6): 329-336$.

582 Benton TG,Vickery J, Wilson JD (2003) Farmland biodiversity: is habitat heterogeneity the

583 key? Trends in ecology and evolution 18 (4): 182-188. https://doi.org/10.1016/S0169-

$584 \quad 5347(03) 00011-9$

585 Bianchi L, Brovelli M, Maltoni A, Calamini G (2013) Confronto tra metodologie di stima della

586 necromassa legnosa in un ceduo invecchiato di leccio. Forest@ 10: 34-42 [online 2013-04-15]

587 URL: $\underline{\text { http://www.sisef.it/forest@/contents/?id=efor0795-010 }}$

588 Biber P, Borges JG, Moshammer R, Barreiro S, Botequim B, Brodrechtova Y Brukas V, Chirici

589 G, Cordero-Debets R, Corrigan E, Eriksson LO, Favero M, Galev E, Garcia-Gonzalo J,

590 Hengeveld G, Kavaliauskas M, Marchetti M, Marques S, Mozgeris G, Navrátil R, Nieuwenhuis

591 M, Orazio O, Paligorov I, Pettenella D, Sedmák R, Smreček R, Stanislovaitis A, Tomé M,

592 Trubins R, Tuček J, Vizzarri M, Wallin I, Pretzsch H, Sallnäs O (2015) How sensitive are

593 ecosystem services in European forest landscapes to silvicultural treatment? Forests 6(5): 16665941695. 
595 Bocock KL (1964) Changes in the amounts of dry matter, nitrogen, carbon, and energy in 596 decomposing woodland leaf litter in relation to the activities of the soil fauna. Journal of Ecology 59752 (2): 273-284. https://doi.org/10.2307/2257595

598 Bowman J, Sleep D, Forbes GJ., Edwards M (2000) The association of small mammals with 599 coarse woody debris at log and stand scales. Forest Ecology and Management 129: 119-124. 600 https://doi.org/10.1016/S0378-1127(99)00152-8

601 Bricker M, Pearson D, Maron J (2010) Small-mammal seed predation limits the recruitment and 602 abundance of two perennial grassland forbs. Ecology 91 (1): 85-92. https://doi.org/10.1890/08$603 \quad \underline{1773.1}$

604 Brockerhoff EG, Jactel H, Parrotta JA, Quine CP, Sayer J (2008) Plantation forests and 605 biodiversity: oxymoron or opportunity? Biodiversity and Conservation 17: 925-951.

606 Brown PR, Huth NI, Banks PB, Singleton GR (2007) Relationship between abundance of 607 rodents and damage to agricultural crops. Agriculture, Ecosystems \& Environment120 : 405-415. 608 https://doi.org/10.1016/j.agee.2006.10.016

609 Burel F, Baudry J, Butet A, Clergeau P, Delettre Y, Le Coeur Dubs F, Morvan N, Paillat G, Petit 610 S, Thenail C, Brunel E, Lefeuvre JC (1998) Comparative biodiversity along a gradient of 611 agricultural landscapes. Acta Oecologica 19 (I): 47-60. https://doi.org/10.1016/S1146$612609 X(98) 80007-6$

613 Burel F, Butet A, Delettre YR, Millàn de la Peña N (2004) Differential response of selected taxa 614 to landscape context and agricultural intensification. Landscape and Urban Planning 67: 195 615 204. https://doi.org/10.1016/S0169-2046(03)00039-2 
616 Burnham KP, Anderson DR (2002) Model selection and multimodel inference: a practical

617 information-theoretic approach. Springer, New York.

618 Butet A, Leroux ABA (2001) Effects of agriculture development on vole dynamics and

619 conservation of Montagu's harrier in western French wetlands. Biological Conservation 100:

620 289-295. https://doi.org/10.1016/S0006-3207(01)00033-7

621 Butet A, Paillat G, Delettre Y (2006) Seasonal changes in small mammal assemblages from field

622 boundaries in an agricultural landscape of western France. Agriculture, Ecosystems \&

623 Environment113: 364-369. https://doi.org/10.1016/j.agee.2005.10.008

624 Caceres NC, Nápoli RP, Hannibal W (2011) Differential trapping success for small mammals

625 using pitfall and standard cage traps in a savannah region of southwestern Brazil. Mammalia 75:

626 45-52. https://doi.org/10.1515/mamm.2010.069

627 Cagnin M, Moreno S, Aloise G, Garofalo G, Villafuerte R, Gaona P, Cristaldi M (1998)

628 Comparative study of Spanish and Italian terrestrial small mammals coenoses from different

629 biotopes in Mediterranean peninsular tip regions. Journal of Biogeography 25: 1105-1113.

630 https://doi.org/10.1046/j.1365-2699.1998.00248.x

631 Canova L, Fasola M (1991) Communities of small mammals in six biotopes of northern Italy.

632 Acta Theriologica 36 (1-2): 73-86.

633 Canova L, Fasola M (1993) Food habits and trophic relationships of small mammals in six

634 habitats of the northern Po plain (Italy). Mammalia 57 (2): 189-200.

635 https://doi.org/10.1515/mamm.1993.57.2.189 
636 Capizzi D, Battistini M, Amori G (2003) Effects of habitat fragmentation and forest management

637 on the distribution of the edible dormouse Glis glis. Acta Theriologica 48: 359-371.

638 https://doi.org/10.1007/BF03194175

639 Capizzi D, Bertolino S, Mortelliti A (2014) Rating the rat: global patterns and research priorities

640 in impacts and management of rodent pests. Mammal Review 44 (2): 148-162.

641 https://doi.org/10.1111/mam.12019

642 Capizzi D, Santini L (2007) I Roditori italiani. Ecologia, impatto sulle attività umane e sugli

643 ecosistemi, gestione delle popolazioni. Antonio Delfino Editore, Roma.

644 Carey AB, Harrington CA (2001) Small mammals in young forest: implications for management

645 for sustainability. Forest Ecology and Management 154: 289-309. https://doi.org/10.1016/S0378-

$646 \quad \underline{1127(00) 00638-1}$

647 Carvell C, Osborne JL, Bourke AFG, Freeman SN, Pywell RF, Heard MS (2011). Bumble bee

648 species' responses to a targeted conservation measure depend on landscape context and habitat

649 quality. Ecological Applications 21 (5). 1760-1771. https://doi.org/10.1890/10-0677.1

650 Christian DP, Collins PT, Hanowski JM, Niemi GJ (1997) Bird and small mammal use of short-

651 rotation hybrid poplar plantations. The Journal of WildlifeManagement 61: 171-182.

652 https://doi.org/10.2307/3802426

653 Christian DP, Hoffman W, Hanowski JM, Niemi GJ, Beyea J (1998) Bird and mammal diversity

654 on woody biomass plantations in North America. Biomass and Bioenergy 14 (4): 395-402.

655 https://doi.org/10.1016/S0961-9534(97)10076-9

656 Cox MPG, Dickman CR, Cox WG (2000) Use of habitat by the black rat (Rattus rattus) at North

657 Head, New South Wales: an observational and experimental study. Austral Ecology 25: 375-385.

658 https://doi.org/10.1046/j.1442-9993.2000.01050.x 
659 Dainese M, Luna D I, Sitzia T, Marini L (2015) Testing scale-dependent effects of seminatural

660 habitats on farmland biodiversity. Ecological Applications 25: 1681-1690.

661 https://doi.org/10.1890/14-1321.1

662 Dainese M, Montecchiari S, Sitzia T, Sigura M, Marini L (2016) High cover of hedgerows in the 663 landscape supports multiple ecosystem services in Mediterranean cereal fields. Journal of 664 Applied Ecology 54 (2): 380-388. https://doi.org/10.1111/1365-2664.12747

665 Decocq G, Andrieu E, Brunet J, Chabrerie O, De Frenne P, De Smedt P, Deconchat M, 666 Diekmann M, Ehrmann S, Giffard B, Gorriz Mifsud E, Hansen K, Hermy M, Kolb A, Lenoir J, 667 Liira J, Moldan F, Prokofieva I, Rosenqvist L, Varela E, Valdés A, Verheyen K, Wulf M (2016) 668 Ecosystem services from small forest patches in agricultural landscapes. Current Forestry 669 Reports 2(1): 30-44.

670 Denny KN, Bilodeau KN, Dumont CA, Olson ZH (2021) Separating effects of spatial location 671 and microhabitat density on perceived predation risk in small mammals. acta ethologica, 24(2), 672 79-85. https://doi.org/10.1007/s10211-021-00365-y

673 De Simone S, Sigura M, Boscutti F (2017) Patterns of biodiversity and habitat sensitivity in 674 agricultural landscapes. Journal of Environmental Planning and Management 60 (7): 1173-1192. 675 http://dx.doi.org/10.1080/09640568.2016.1205971

676 Dickman CR, Doncaster CP (1987) The ecology of small mammals in urban habitats. I.

677 Populations in a patchy environment. Journal of Animal Ecology 56 (2): 629-640.

678 https://doi.org/10.2307/5073 
679 Dondina O, Kataoka L, Orioli V, Bani L (2016) How to manage hedgerows as effective

680 ecological corridors for mammals: A two-species approach. Agriculture, Ecosystems \&

681 Environment 231: 283-290. https://doi.org/10.1016/j.agee.2016.07.005

682 Dorigo L (2018) Eterogeneità del paesaggio agricolo e piccoli mammiferi in agroecosistemi: un 683 approccio multiscala. $\mathrm{PhD}$ Thesis, University of Udine.

684 Fahrig L (2007) Non-optimal animal movement in human-altered landscapes. Functional

685 Ecology 21: 1003-1015. https://doi.org/10.1111/j.1365-2435.2007.01326.x

686 FAO (2015) Global Forest Resources Assessment 2015. How are the World's Forests Changing?

687 Second edition. FAO, Rome.

688 Faraway JJ (2005) Extending the Linear Model with R: Generalized Linear, Mixed Effects and 689 Nonparametric Regression Models. CRC Press.

690 Fischer J, Abson DJ, Butsic V, Chappell MJ, Ekroos J, Hanspach J, Kuemmerle T, Henrik G,

691 Smith HG, von Wehrden H (2014) Land Sparing Versus Land Sharing: Moving Forward.

692 Conservation Letters 7 (3): 149-157. https://doi.org/10.1111/conl.12084_2014

693 Fischer J, Lindenmayer DB, Manning AD (2006) Biodiversity, ecosystem function, and

694 resilience: Ten guiding principles for commodity production landscapes. Frontiers in Ecology

695 and the Environment 4: 80-86. https://doi.org/10.1890/1540-

696 9295(2006)004[0080:BEFART]2.0.CO;2

697 Fischer C, Schröder B (2014) Predicting spatial and temporal habitat use of rodents in a highly

698 intensive agricultural area. Agriculture, Ecosystems \& Environment 189: 145-153.

699 https://doi.org/10.1016/j.agee.2014.03.039 
700 Fischer C, Thies C, Tscharntke T (2011) Small mammals in agricultural landscapes: Opposing

701 responses to farming practices and landscape complexity. Biological Conservation 144: 1130-

702 1136. https://doi.org/10.1016/j.biocon.2010.12.032

703 Fitzgibbon CD (1997) Small Mammals in Farm Woodlands: The Effects of Habitat, Isolation

704 and Surrounding Land-Use Patterns. Journal of Applied Ecology 34 (2): 530-539.

705 https://doi.org/10.2307/2404895

706 Fitzgibbon SI, Putland DA, Goldizen AW (2007) The importance of functional connectivity in

707 the conservation of ground dwelling mammal in urban Australian landscape. Landscape Ecology

708 22: 1513-1525. https://doi.org/10.1007/s10980-007-9139-X

709 Fontana A (2006) Evoluzione geomorfologica della bassa pianura friulana e sue relazioni con le

710 dinamiche insediative antiche. Ed. del Museo Friulano di Storia Naturale, Udine.

711 Fox J, Weisberg S (2011) An R companion to applied regression, 2nd edn. SAGE Publications.

712 Fuentes-Montemayor E, Ferryman M, Watts K, Macgregor NA, Hambly N, Brennan S, Coxon

713 R, Langridge H Park KJ (2020) Small mammal responses to long-term large-scale woodland

714 creation: the influence of local and landscape-level attributes. Ecological Applications, 30(2),

715 e02028. https://doi.org/10.1002/eap.2028

716 Gagné SA, Eigenbrod F, Bert DG, Cunnington GM, Olson LT, Smith AC, Fahrig L (2015) A

717 simple landscape design framework for biodiversity conservation. Landscape and Urban

718 Planning 136: 13-27. https://doi.org/10.1016/j.landurbplan.2014.11.006

719 Geiger F, Bengtsson J, Berendse F, Weisser WW, Emmerson M, Morales MB, Ceryngier P,

720 Liira J, Tscharntke T, Winqvist C, Eggers S, Bommarco R, Pärt T, Bretagnolle V, Plantegenest

721 M, Clement LW, Dennis C, Palmer C, Oñate JJ, Guerrero I, Hawro V, Aavik T, Thies C, Flohre

722 A, Hänke S, Fischer C, Goedhart PW, Inchausti P (2010) Persistent negative effects of pesticides 
723 on biodiversity and biological control potential on European farmland. Basic and Applied

724 Ecology 11 (2): 97-105. https://doi.org/10.1016/j.baae.2009.12.001

725 Fragoso R, Santos-Reis M, Rosalino LM (2020) Drivers of wood mouse body condition in

726 Mediterranean agroforestry landscapes. European Journal of Wildlife Research, 66(1), 1-11.

727 https://doi.org/10.1007/s10344-019-1356-5

728 Gelling M, Macdonald DW, Mathews F (2007) Are hedgerows the route to increased farmland 729 small mammal density? Use of hedgerows in British pastoral habitats. Landscape

730 Ecology, 22(7), 1019-1032.

731 Gentili S, Sigura M, Bonesi L (2014) Decreased small mammals species diversity and increased

732 population abundance along a gradient of agricultural intensification. Hystrix 25 (1): 39-44.

733 http://dx.doi.org/10.4404/hystrix-25.1-9246

734 Geuse P, Bauchau V, Le Boulengé E (1985) Distribution and population dynamics of bank voles

735 and wood mice in a patchy woodland habitat in central Belgium. Acta Zoologica Fennica 173:

$736 \quad 65-68$.

737 Gliwicz J, Taylor JR (2002) Comparing life histories of shrews and rodents. Acta

738 Theriologica 47 (1): 185-208. https://doi.org/10.1007/BF03192487

739 Greene R, Martin JA, Wigley TB (2019) 1 Short-Rotation Woody Crops and Wildlife

740 Conservation. In: Moorman CE, Grodsky SM, Rupp S (Eds). Renewable energy and wildlife

741 conservation. JHU Press.Renewable Energy and Wildlife Conservation, 13.

742 Halle S (1993) Wood mice (Apodemus sylvaticus L.) as pioneers of recolonization in a reclaimed

743 area. Oecologia 94: 120-127. https://doi.org/10.1007\%2FBF00317312 
744 Hanowski JM, Niemi GJ, Christian DC (1997) Influence of Within-Plantation Heterogeneity and

745 Surrounding Landscape Composition on Avian Communities in Hybrid Poplar Plantations.

746 Conservation Biology 11 (4): 936-944.

747 Hansson L (1978) Small mammal abundance in relation to environmental variables in three

748 Swedish forest phases. Studia Forestalia Suecica 147: 1-40.

749 Hansson L (1985) The food of bank voles, wood mice and yellow-necked mice. Symposium of 750 the Zoological Society of London 55: 141-168.

751 Harmon ME, Franklin JF, Swanson FJ, Sollins P, Gregory SV, Lattin JD, Anderson NH, Cline

752 SP, Aumen NG, Sedell JR, Lienkaemper GW, Cromack K, Cummins KW (1986) Ecology of

753 coarse woody debris in temperate ecosystems. Advances in Ecological Research 15: 133-302.

754 https://doi.org/10.1016/S0065-2504(08)60121-X

755 Harmon ME, Sexton J (1996) Guidelines for measurements of woody detritus in forest

756 ecosystems. Publ. 20, US. Longterm Ecological Research Network Office, University of

757 Washington, Seattle, USA.

758 He W, Ma Z, Pei J, Teng M, Zeng L, Yan Z, Huang Z, Zhou Z, Wang P, Luo X, Xiao W (2019)

759 Effects of predominant tree species mixing on lignin and cellulose degradation during leaf litter

760 decomposition in the Three Gorges Reservoir, China. Forests, 10(4), 360.

761 https://doi.org/10.3390/f10040360

762 Heroldová M, Bryja J, Zejda J, Tkadlec E (2007) Structure and diversity of small mammal

763 communities in agriculture landscape. Agriculture, Ecosystems \& Environment 120: 206-210.

764 https://doi.org/10.1016/j.agee.2006.09.007 
765 Kaminski JR, Davis ML, Kelly M, Keyser PD (2007) Disturbance effects on small-mammal

766 species in a managed Appalachian forest. American Midland Naturalist 157: 385-397.

767 https://doi.org/10.1674/0003-0031(2007)157[385:DEOSMS]2.0.CO;2

768 Kemper C, Bell DT (1985) Small mammals and habitat structure in lowland rain forest of

769 Peninsular Malaysia. Journal of Tropical Ecology 1 (01): 5-22.

770 https://doi.org/10.1017/S0266467400000043

771 Klaa K, Mill PJ, Incoll LD (2005) Distribution of small mammals in a silvoarable agroforestry

772 system in Northern England. Agroforestry systems 63: 101-110.

773 https://doi.org/10.1007\%2Fs10457-004-1110-0

774 Kleijn D, Rundlöf M, Scheper J, Smith HG, Tscharntke T (2011) Does conservation on farmland

775 contribute to halting the biodiversity decline? Trends in Ecology and Evolution 26 (9): 474-481.

776 https://doi.org/10.1016/j.tree.2011.05.009

777 Koivula M, Punttila P, Haila Y, Niemela J (1999) Leaf litter and the small-scale distribution of

778 carabid beetles (Coleoptera, Carabidae) in the boreal forest. Ecography 22: 424-435.

779 https://doi.org/10.1111/j.1600-0587.1999.tb00579.x

780 Korpimaki E, Norrdahl K (1991) Numerical and functional responses of kestrels, short-eared

781 owls, and long-eared owls to vole densities. Ecology 72: 814-826.

782 https://doi.org/10.2307/1940584

783 Kozakiewicz M, Gortat T, Kozakiewicz A, Barkowska M (1999) Effects of habitat

784 fragmentation on four rodent species in a Polish farm landscape. Landscape Ecology 14 (4): 391 -

785 400. https://doi.org/10.1023\%2FA\%3A1008070610187

786 Kuncová P, Frynta D (2009) Interspecific morphometric variation in the postcranial skeleton in

787 the genus Apodemus. Belgian Journal of Zoology 139 (2): 133-46. 
788 Laundré JW, Reynolds TD (1993) Effects of soil structure on burrow characteristics of five small

789 mammal species. The Great Basin Naturalist 53 (4): 358-366.

790 Le Roux X, Barbault R, Baudry J, Burel F, Doussan I, Garnier E, Herzog F, Lavorel S, Lifran R,

791 Roger-Estrade J, Sarthou J-P, Trommetter M (Eds) (2008) Agriculture et Biodiversite'. Valoriser

792 les Synergies. Expertise scientifique collective, synthese du rapport, INRA, France.

793 Lindenmayer DB, Hobbs RJ, Salt D (2003) Plantation forests and biodiversity conservation.

794 Australian Forestry 66 (1): 62-66.

795 Liro A, Szacki J (1987) Movements of field mice Apodemus agrarius (Pallas) in a suburban

796 mosaic of habitats. Oecologia 74 (3): 438-440. https://doi.org/10.1007\%2FBF00378942

797 Lovell ST, De Santis S, Nathan CA, Breton Olson M, Mendez VE, Kominami HC, Erickson DL,

798 Morris KS, Morris WB (2010) Integrating Agroecology and Landscape Multifunctionality in

799 Vermont: An Evolving Framework to Evaluate the Design of Agroecosystems.Agricultural

800 Systems 103: 327-341. doi:10.1016/j.agsy.2010.03.003

801 Macdonald DW, Tattersall FH, Service KM, Firbank LG, Feber RE (2007) Mammals, agri-

802 environment schemes and set-aside - what are the putative benefits? Mammal Review 37 (4):

803 259-277. https://doi.org/10.1046/j.1440-1770.2002.00172_37_4.x

804 Macdonald DW, Tew TE, Todd IA, Garner JP, Johnson PJ (2000) Arable habitat use by wood

805 mice (Apodemus sylvaticus) 3. A farm-scale experiment on the effects of crop rotation. Journal

806 of Zoology 250 (3): 313-320. https://doi.org/10.1111/j.1469-7998.2000.tb00775.x

807 Marsh ACW, Harris S (2000) Partitioning of woodland habitat resources by two sympatric

808 species of Apodemus: Lessons for the conservation of the yellow-necked mouse (A. flavicollis) in

809 Britain. Biological Conservation 92: 275-283. https://doi.org/10.1016/S0006-3207(99)00071-3 
810 Martin SK (1994) Feeding ecology of American martens and fishers. In: Buskirk SW, Harestad

811 AS, Raphael MG, Powell RA (Eds.), Martens, Sables, and Fishers. Biology and Conservation.

812 Comstock Publishing Association. Cornell University Press, Ithaca and London, pp 297-315.

813 Mathews CP, Kowalczewski A (1969) The disappearance of Leaf Litter and its Contribution to

814 Production in the River Thames. Journal of Ecology 57 (2): 543-552.

815 https://doi.org/10.2307/2258398

816 McCay TS (2000) Use of woody debris by cotton mice (Peromyscus gossypinus) in a

817 southeastern pine forest. Journal of Mammalogy 81 (2): 527-535. https://doi.org/10.1644/1545-

$818 \quad \underline{1542(2000) 081<0527: \mathrm{UOWDBC}>2.0 . \mathrm{CO} ; 2}$

819 McGarigal K, Cushman SA, Ene E (2012) FRAGSTATS v4: Spatial Pattern Analysis Program

820 for Categorical and Continuous Maps. Computer software program produced by the authors at 821 the University of Massachusetts, Amherst.

822 McGarigal K, Marks BJ (1995) Spatial pattern analysis program for quantifying landscape 823 structure. Gen. Tech. Rep. PNW-GTR-351. US Department of Agriculture, Forest Service,

824 Pacific Northwest Research Station.

825 Michel N, Burel F, Butet A (2006) How does landscape use influence small mammal diversity, 826 abundance and biomass in hedgerow networks of farming landscapes? Acta Oecologica 30: 11827 20. https://doi.org/10.1016/j.actao.2005.12.006

828 Millàn de la Peña N, Butet A, Delettre Y, Paillat G, Morant P, LeDu L, Burel F (2003) Response 829 of the small mammal community to changes in western French agricultural landscapes.

830 Landscape Ecology 18: 265-278. https://doi.org/10.1023\%2FA\%3A1024452930326 
831 Miller DH, Getz LL (1977) Factors influencing local distribution and species diversity of forest

832 small mammals in New England. Canadian Journal of Zoology 55: 806-814.

833 https://doi.org/10.1139/z77-105

834 Montgomery WI (1980). The use of arboreal runways by the woodland rodents, Apodemus

835 sylvaticus (L.), A. flavicollis (Melchior) and Clethrionomys glareolus (Schreber). Mammal

836 Review 10 (4):189-195. https://doi.org/10.1111/j.1365-2907.1980.tb00239.x

837 Mortelliti A, Santarelli L, Sozio G, Fagiani S, Boitani L (2013) Long distance field crossings by

838 hazel dormice (Muscardinus avellanarius) in fragmented landscapes. Mammalian Biology 78:

839 309-312. https://doi.org/10.1016/j.mambio.2012.09.006

840 Mortelliti A, Westgate MJ, Lindenmayer DB (2014) Experimental evaluation shows limited

841 influence of pine plantations on the connectivity of highly fragmented bird populations. Journal

842 of Applied Ecology 51 (5): 1179-1187.

843 Moser BW, Pipas MJ, Witmer GW, Engeman RM (2002) Small Mammal Use of Hybrid Poplar

844 Plantations Relative to Stand Age. Northwest Science 76 (2): 158-165.

845 Norton DA (1998) Indigenous biodiversity conservation and plantation forestry: options for the

846 future. New Zealand Forestry 43: 34-39.

847 Nykvist N (1962) Leaching and decomposition of litter. V. Experiments on Leaf Litter of Alnus 848 glutinosa, Fagus sylvatica and Quercus robur. Oikos 13 (2): 232-248.

849 https://doi.org/10.2307/3565087

850 Orlandi A, Paolucci P (2004) Biologia ed ecologia del topo selvatico dal dorso striato (Apodemus 851 agrarius) (Mammalia, Muridae). Ricerche naturalistiche a Bosco Fontana - Quaderni

852 Conservazione Habitat 3: 79-86. 
853 Ouin A, Paillat G, Butet A, Burel F (2000) Spatial dynamics of Wood Mouse (Apodemus

854 sylvaticus) in an agricultural landscape under intensive use in the Mont Saint Michel Bay

855 (France). Agriculture, Ecosystems \& Environment 78: 159-165. https://doi.org/10.1016/S0167-

$856 \quad \underline{8809(99) 00119-X}$

857 Paise G, Vieira EM, Prado PI (2020) Small mammals respond to extreme habitat fragmentation

858 in the Brazilian Atlantic Forest according to the landscape continuum model. Mammal Research, 859 65(2), 309-322. https://doi.org/10.1007/s13364-019-00464-z

860 Palmeirim AF, Santos-Filho M, Peres CA (2020) Marked decline in forest-dependent small

861 mammals following habitat loss and fragmentation in an Amazonian deforestation frontier. PloS

862 one, 15(3), e0230209. https://doi.org/10.1371/journal.pone.0230209

863 Pearce J, Venier L (2005) Small mammals as bioindicators of sustainable boreal forest

864 management. Forest Ecology and Management 208 (1): 153-175.

865 https://doi.org/10.1016/j.foreco.2004.11.024

866 Pielou EC (1975) Ecology diversity. J. Wiley and Sons, New York.

867 Piper RW, Lewis Z, Compton SG (2014) Life in the leaf-litter: a novel metal detector technique

868 to investigate the over-wintering survival of rare, case-bearing beetle larvae. Journal of Insect

869 Conservation 18: 1163-1169. https://doi.org/10.1007/s10841-014-9727-4

870 Pinheiro J, Bates D, DebRoy S, Sarkar D, R Core Team (2017) nlme: Linear and Nonlinear

871 Mixed Effects Models. R package version, 3.1-131.

872 Putman RJ (1989) Mammals as pests. Chapman and Hall, London.

873 R Core Team (2021) R: A language and environment for statistical computing. R Foundation for 874 Statistical Computing, Vienna, Austria. URL https://www.R-project.org/. 
875 Rosalino LM, Ferreira D, Leitao I, Santos-Reis M (2011) Selection of nest sites by wood mice 876 Apodemus sylvaticus in a Mediterranean agro-forest landscape. Ecological Research 26: 445877 452. https://doi.org/10.1007/s11284-010-0797-9

878 Sabo JL, Soykan CU, Keller A (2005) Functional roles of leaf litter detritus in terrestrial food 879 webs. In: De Ruiter P, Wolters V, Moore JC, Melville-Smith K. (Eds.) Dynamic Food Webs. 880 Multispecies Assemblages, Ecosystem Development, and Environmental Change. Volume 3, 881 Theoretical Ecology Series, pp 211-222.

882 Salamolard M, Butet A, Leroux A, Bretagnolle V (2000) Responses of an avian predator to 883 variations in prey density at a temperate latitude. Ecology 81:2428-2441.

884 https://doi.org/10.1890/0012-9658(2000)081[2428:ROAAPT]2.0.CO;2

885 Šálek M, Kreisinger J, Sedláček F, Albrecht T (2010). Do prey densities determine preferences 886 of mammalian predators for habitat edges in an agricultural landscape? Landscape and Urban

887 Planning 98(2): 86-91. https://doi.org/10.1016/j.landurbplan.2010.07.013

888 Serafini VN, Priotto JW, Gomez MD (2019) Effects of agroecosystem landscape complexity on

889 small mammals: a multi-species approach at different spatial scales. Landscape Ecology, 34(5),

890 1117-1129. https://doi.org/10.1007/s10980-019-00825-8

891 Sieg CH (1987) Small Mammals: Pest or Vital Components of the Ecosystem. VIII Wildlife

892 Damage Control Workshop, 26-30 april 1987, Rapid City, South Dakota, pp 88-92.

893 Silva M, Hartling L, Opps SB (2005) Small mammals in agricultural landscapes of Prince

894 Edward Island (Canada): Effects of habitat characteristics at three different spatial scales.

895 Biological Conservation 126: 556-568. https://doi.org/10.1016/j.biocon.2005.07.007

896 Silva M, Prince ME (2008) The conservation value of hedgerows for small mammals in Prince 897 Edward Island, Canada. The American Midland Naturalist, 159(1), 110-124. 
898 Simonetti JA (1989) Microhabitat use by small mammals in central Chile. Oikos 56: 309-318.

899 https://doi.org/10.2307/3565615

900 Sozio G, Mortelliti A, Boitani L (2013) Mice on the move: wheat rows as a means to increase

901 permeability in agricultural landscapes. Biological Conservation 165: 198-202.

902 https://doi.org/10.1016/j.biocon.2013.05.022

903 Speelman EN, García-Barrios LE, Groot JCJ, Tittonell P (2014) Gaming for smallholder 904 participation in the design of more sustainable agricultural landscapes. Agricultural Systems 126:

905 62-75. https://doi.org/10.1016/j.agsy.2013.09.002

906 Steele M, Wauters LA, Larsen KW (2005) Selection, predation and dispersal of seeds by tree

907 squirrels in temperate and boreal forest: are tree squirresls keystone granivores? In: Lambert JE,

908 Hulme PE, Vander Wall SB (Eds.) Seed fate: predation, dispersal and seedling establishment.

909 CABI International, pp 205-221.

910 Szymañski CR, Alvarez JA, Campos CM, Tabeni S (2020) A first assessment of the land

911 management effect on the ecological role of large trees as habitat refuges for desert small

912 mammals. Basic and Applied Ecology, 48, 136-145. https://doi.org/10.1016/j.baae.2020.09.005

913 Tallmon D, Mills S (1994) Use of Logs within Home Ranges of California Red-Backed Voles on

914 a Remnant of Forest. Journal of Mammalogy 75 (1): 97-101. https://doi.org/10.2307/1382240

915 Tattersall FH, Hart BJ, Manley WJ, Macdonald DW, Feber RE (1999) Does the method of set-

916 aside establishment affect its use by wood mice? Journal of Zoology 249: 472-476.

917 https://doi.org/0.1111/j.1469-7998.1999.tb01218.x

918 Tattersall FH, Macdonald DW, Hart BJ, Manley WJ, Feber RE (2001) Habitat use by wood mice

919 (Apodemus agrarius) in a changeable arable landscape. Journal of Zoology 255: 487-494.

920 https://doi.org/10.1017/S095283690100156X 
921 Tew TE, Macdonald DW (1993) The effects of harvest on arable wood mice Apodemus

922 sylvaticus. Biological Conservation 65: 279-283. https://doi.org/10.1016/0006-3207(93)90060-E

923 Tew TE, Todd IA, Macdonald DW (2000) Arable habitat use by wood mice (Apodemus

924 sylvaticus). 2. Microhabitat. Journal of Zoology 250: 305-311. https://doi.org/10.1111/j.1469-

$925 \quad$ 7998.2000.tb00774.x

926 Tresch S, Frey D, Le Bayon RC, Zanetta A, Rasche F, Fliessbach A, Moretti M (2019) Litter

927 decomposition driven by soil fauna, plant diversity and soil management in urban gardens.

928 Science of the Total Environment, 658, 1614-1629.

929 https://doi.org/10.1016/j.scitotenv.2018.12.235

930 Tscharntke T, Klein AM, Kruess A, Steffan-Dewenter I, Thies C (2005) Landscape perspectives

931 on agricultural intensification and biodiversity: ecosystem service management. Ecology Letters

932 8: 857-874. https://doi.org/10.1111/j.1461-0248.2005.00782.x

933 Umetsu F, Naxara L, Pardini R (2006) Evaluating the efficiency of pitfall traps for sampling

934 small mammals in the Neotropics. Journal of Mammalogy 87 (4): 757-765.

935 https://doi.org/10.1644/05-MAMM-A-285R2.1

936 Van Apeldoorn RC, Oostenbrink WT, Van Winden A, Van Der Zee FF (1992) Effects of habitat

937 fragmentation on the bank vole, Clethrionomys glareolus, in an agricultural landscape. Oikos 65

938 (2): 265-274. https://doi.org/10.2307/3545018

939 Vanbeveren SP, Ceulemans R (2019) Biodiversity in short-rotation coppice. Renewable and

940 Sustainable Energy Reviews, 111, 34-43. https://doi.org/10.1016/j.rser.2019.05.012

941 Vickery WL, Bider JR (1981) The influence of weather on rodent activity. Journal of

942 Mammalogy 62 (1): 140-145. https://doi.org/10.2307/1380484 
943 Vieira MV, Olifiers N, Delciellos AC, Antunes VZ, Bernardo LR, Grelle CEV, Cerqueira R

944 (2009) Land use vs. fragment size and isolation as determinants of small mammal composition

945 and richness in Atlantic Forest remnants. Biological Conservation 142: 1191-1200.

946 https://doi.org/10.1016/j.biocon.2009.02.006

947 Yahner RH (1986). Microhabitat Use by Small Mammals in Even-Aged Forest Stands. American

948 Midland Naturalist 115 (1): 174-180. https://doi.org/10.2307/2425847

949 Zitzmann F, Reich M, Schaarschmidt F (2021) Potential of small-scale and structurally diverse

950 short-rotation coppice as habitat for large and medium-sized mammals. Biologia, 1-12.

951 https://doi.org/10.1007/s11756-021-00686-0

952 Zulian E (1987) Reperti sulla distribuzione e sulla biologia di Apodemus agrarius (Pallas)

953 (Rodentia Muridae) nell'Italia nord-orientale. Lavori Società veneziana Scienze naturali 12: 133-

954147.

955 Zuur AF, Ieno EN, Walker NJ, Saveliev AA, Smith GM (2009) Mixed Effects Models and

956 Extensions in Ecology with R. Springer, New York, NY, USA.

957 


\section{Table $\mathbf{1}$ (on next page)}

List of plausible models performed with multi-model inference for microhabitat structure

List of plausible models performed with multi-model inference for microhabitat structure. The estimates are reported: the intercept (Int), the variables considered in each model (ddW = mean percentage of surface around the traps occupied by deadwood; grn = mean percentage of surface around the traps occupied by bare soil; spcs = species; und = mean percentage of undecomposed litter in the litter stratum), $\mathrm{R}^{2}, \mathrm{AIC}, \triangle \mathrm{AIC}$ and model weight (wi). In bold Relative Variable Importance values and significance 


\begin{tabular}{|c|c|c|c|c|c|c|c|c|c|c|c|c|}
\hline (Int) & $\mathrm{ddW}$ & grn & spcs & & und & ddW:spes & grn:spcs & spcs:und & $\mathrm{R}^{\wedge} 2$ & $\mathrm{AIC}$ & delta & weight \\
\hline 126.7 & -0.25 & 0.03 & & + & -1.30 & + & + & + & 0.29 & 344.6 & 0 & 0.11 \\
\hline 127.5 & -0.26 & & & + & -1.31 & + & & + & 0.29 & 344.9 & 0.31 & 0.10 \\
\hline 127.4 & -0.26 & 0.00 & & + & -1.31 & + & & + & 0.29 & 345.4 & 0.87 & 0.07 \\
\hline 120 & & 0.13 & & + & -1.25 & & + & + & 0.28 & 345.6 & 1.04 & 0.07 \\
\hline 122.4 & & & & + & -1.27 & & & + & 0.27 & 345.6 & 1.05 & 0.07 \\
\hline 111.3 & 0.33 & 0.26 & & + & -1.17 & & + & + & 0.28 & 345.9 & 1.38 & 0.06 \\
\hline 116.1 & 0.33 & & & + & -1.23 & & & + & 0.28 & 346.2 & 1.59 & 0.05 \\
\hline 124.8 & & -0.13 & & + & -1.30 & & & + & 0.27 & 346.4 & 1.8 & 0.05 \\
\hline & 0.71 & 0.68 & & 1 & 0.86 & 0.46 & 0.44 & 0.72 . & & & & \\
\hline
\end{tabular}

1 


\section{Table 2 (on next page)}

List of plausible models performed with multi-model inference at wood structure scale List of plausible models performed with multi-model inference at wood structure scale. The estimates are reported: the intercept (Int), the variables considered in each model (Tree_dns $=$ tree density; Mean_dmt $=$ mean trunk diameter; Tree_spcs $=$ number of tree species;

Shr_spcs = number of shrub species; spcs = species), $\mathrm{R}^{2}$, AIC, $\triangle \mathrm{AIC}$ and model weight (wi). In bold Relative Variable Importance values and significance 


\begin{tabular}{|c|c|c|c|c|c|c|c|c|c|c|c|c|c|c|}
\hline & & Mean_dm & & & & & Tree_dns: & Mean_dm & Tree_spcs & Shr_spcs: & & & & \\
\hline (Int) & Tree_dns & $\mathrm{t}$ & Tree_spcs & Shr_spcs & spcs & & spcs & $\mathrm{t}$ :spes & :spcs & spcs & $\mathrm{R}^{\wedge} 2$ & AIC & delta & weight \\
\hline 95.33 & 0.57 & -1.01 & -6.66 & -1.89 & & + & + & + & + & + & 0.28 & 333.7 & 0 & 0.23 \\
\hline 75.24 & 0.94 & & -6.98 & -2.90 & & + & + & & + & + & 0.22 & 334.1 & 0.36 & 0.19 \\
\hline 94.61 & 0.60 & -1.01 & -6.66 & -1.85 & & + & & + & + & + & 0.28 & 334.8 & 1.1 & 0.13 \\
\hline 84.17 & 0.77 & -0.45 & -6.8 & -2.45 & & + & + & & + & + & 0.24 & 334.8 & 1.11 & 0.13 \\
\hline 106.4 & & -1.06 & -6.74 & -2.56 & & + & & + & + & + & 0.26 & 334.9 & 1.21 & 0.12 \\
\hline 78.33 & 0.77 & & -7.01 & -3.13 & & + & & & + & + & 0.22 & 335.2 & 1.46 & 0.11 \\
\hline 92.39 & & & -7.15 & -4.14 & & + & & & + & + & 0.20 & 335.6 & 1.83 & 0.10 \\
\hline & 0.75 & 0.66 & 0.99 & 0.95 & & 1 & 0.48 & 0.42 & 0.9 & 0.83 & & & & \\
\hline
\end{tabular}

1 


\section{Table 3 (on next page)}

List of plausible models performed with multi-model inference for landscape configuration in $250 \mathrm{~m}$ buffer

List of plausible models performed with multi-model inference for landscape configuration in $250 \mathrm{~m}$ buffer. The estimates are reported: the intercept (Int), the variables considered in each model (Are_prm = area/perimeter ratio of wood patches, PSI = patch shape index), $\mathrm{R}^{2}$, AIC, $\triangle \mathrm{AIC}$ and model weight (wi). In bold Relative Variable Importance values and significance 


\begin{tabular}{|c|c|c|c|c|c|c|c|c|c|}
\hline \multirow[t]{2}{*}{ (Int) } & \multicolumn{3}{|c|}{ PSI } & \multirow[t]{2}{*}{ Are_prm:spcs } & \multirow[t]{2}{*}{ PSI:spcs } & \multirow[t]{2}{*}{$\mathrm{R}^{\wedge} 2$} & \multirow[t]{2}{*}{ AIC } & \multirow[t]{2}{*}{ delta } & \multirow[t]{2}{*}{ weight } \\
\hline & Are_prm & & spcs & & & & & & \\
\hline 38,7 & & 3,52 & + & & + & 0,06 & 342,9 & 0 & 0,45 \\
\hline 26,01 & 0,43 & 5,17 & + & & + & 0,1 & 343,7 & 0,83 & 0,3 \\
\hline 32,87 & 0,2 & 4,28 & + & & + & 0,11 & 344,1 & 1,19 & 0,25 \\
\hline & 0,55 & 0,99 & 1 & 0,25 & 0,91 & & & & \\
\hline
\end{tabular}

1 


\section{Table 4 (on next page)}

List of plausible models performed with multi-model inference for landscape configuration in $500 \mathrm{~m}$ buffer

List of plausible models performed with multi-model inference for landscape configuration in $500 \mathrm{~m}$ buffer. The estimates are reported: the intercept (Int), the variables considered in each model (Are_prm = area/perimeter ratio of wood patches, PSI = patch shape index, MSI_500 = Modified Simpson's Diversity Index in $500 \mathrm{~m}$ buffer), $\mathrm{R}^{2}$, AIC, $\triangle$ AIC and model weight (wi). In bold Relative Variable Importance values and significance 


\begin{tabular}{|c|c|c|c|c|c|c|c|c|c|c|c|}
\hline (Int) & & & PSI & & Are_prm:spcs & & PSI:spcs & $\mathrm{R}^{\wedge} 2$ & AIC & delta & weight \\
\hline & Are_prm & MSI_500 & & spcs & & MSI_500:spcs & & & & & \\
\hline 38,7 & & & 3,52 & + & & & + & 0,06 & 342,9 & 0 & 0,19 \\
\hline$-18,15$ & & 0,57 & 6,78 & + & & + & + & 0,2 & 343,3 & 0,41 & 0,15 \\
\hline 26,01 & 0,43 & & 5,17 & + & & & + & 0,09 & 343,7 & 0,83 & 0,12 \\
\hline$-15,68$ & $-0,15$ & 0,59 & 6,31 & + & + & + & + & 0,26 & 343,9 & 1,04 & 0,11 \\
\hline 32,87 & 0,2 & & 4,28 & + & + & & + & 0,11 & 344,1 & 1,19 & 0,1 \\
\hline$-23,34$ & 0,31 & 0,53 & 7,75 & + & & + & + & 0,22 & 344,7 & 1,84 & 0,07 \\
\hline 15,32 & & 0,23 & 4,86 & + & & & + & 0,11 & 344,8 & 1,88 & 0,07 \\
\hline & 0,54 & 0,55 & 0,99 & 1 & 0,27 & 0,39 & 0,91 & & & & \\
\hline
\end{tabular}

1 


\section{Table 5 (on next page)}

List of plausible models performed with multi-model inference for landscape composition in $250 \mathrm{~m}$ buffer

List of plausible models performed with multi-model inference for landscape composition in $250 \mathrm{~m}$ buffer. The estimates are reported: the intercept (Int), the variables considered in each model (crp_250 = percentage of surface area occupied by crops; prm_250 = percentage of surface area occupied by permanent crops; stt_250 = percentage of surface area occupied by settlements), $\mathrm{R}^{2}, \mathrm{AIC}, \triangle \mathrm{AIC}$ and model weight (wi). In bold Relative Variable Importance values and significance 


\begin{tabular}{|c|c|c|c|c|c|c|c|c|c|c|c|}
\hline (Int) & crp_250 & prm_250 & stt_250 & spcs & crp_250:spcs & prm_250:spcs & stt_250:spcs & $\mathrm{R}^{\wedge} 2$ & $\mathrm{AIC}$ & delta & weight \\
\hline 32.16 & & 0.96 & -0.46 & + & & + & & 0.36 & 345.3 & 0 & 0.29 \\
\hline 27.81 & & 1.01 & & + & & + & & 0.30 & 345.3 & 0.06 & 0.28 \\
\hline 34.72 & & 0.92 & -0.73 & + & & + & + & 0.37 & 345.6 & 0.38 & 0.24 \\
\hline 90.76 & -0.77 & & -1.4 & + & + & & + & 0.38 & 346 & 0.75 & 0.20 \\
\hline & 0.44 & $0.8 *$ & 0.72 & 1 & 0.28 & $0.71 *$ & 0.43 & & & & \\
\hline
\end{tabular}

1 


\section{Table 6(on next page)}

List of plausible models performed with multi-model inference for landscape composition in $500 \mathrm{~m}$ buffer

List of plausible models performed with multi-model inference for landscape composition in $500 \mathrm{~m}$ buffer. The estimates are reported: the intercept (Int), the variables considered in each model (crp_500 = percentage of surface area occupied by crops; prm_500 percentage of surface area occupied by permanent crops; stt_500 = percentage of surface area occupied by settlements), $\mathrm{R}^{2}, \mathrm{AIC}, \triangle \mathrm{AIC}$ and model weight (wi). In bold Relative Variable Importance values and significance 


\begin{tabular}{|c|c|c|c|c|c|c|c|c|c|c|c|}
\hline (Int) & crp_500 & prm_500 & stt_500 & spcs & crp_500:spcs & prm_500:spcs & stt_500:spc & $\mathrm{R}^{\wedge} 2$ & AIC & delta & weight \\
\hline 24,08 & & 1,25 & & + & & + & & 0,31 & 343,9 & 0 & 0,25 \\
\hline 29,18 & & 1,14 & $-0,38$ & + & & + & & 0,35 & 344,8 & 0,95 & 0,15 \\
\hline 0,96 & 0,34 & 1,49 & & + & & + & & 0,34 & 345,1 & 1,26 & 0,13 \\
\hline & 0,47 & $0,94 *$ & 0,51 & 1 & 0,21 & $0,89 *$ & 0,21 & & & & \\
\hline
\end{tabular}

1 


\section{Table 7 (on next page)}

List of plausible models performed with multi-model inference in $250 \mathrm{~m}$ buffer

List of plausible models performed with multi-model inference in $250 \mathrm{~m}$ buffer. The estimates are reported: the intercept (Int), the variables considered in each model (prm_250 = percentage of surface area occupied by permanent crops; spcs = species; und = undecomposed litter percentage), $\mathrm{R}^{2}, \mathrm{AIC}, \triangle \mathrm{AIC}$ and model weight (wi). In bold Relative Variable Importance values and significance 


\begin{tabular}{|c|c|c|c|c|c|c|c|c|c|c|}
\hline (Int) & prm 250 & spcs & und & prm 250:spcs & spcs:und & $\mathrm{R}^{\wedge} 2$ & AIC & delta & \multicolumn{2}{|c|}{ weight } \\
\hline \multirow[t]{2}{*}{20,68} & & + & & + & + & 0,56 & 214,8 & & 0 & 0,748 \\
\hline & $\mathbf{0 , 7 3} * * *$ & 0,91 . & $\mathbf{0 , 8 1} * * *$ & $0,7 * * *$ & $0, \mathbf{7 5}^{* * *}$ & & & & & \\
\hline
\end{tabular}

1 


\section{Table 8(on next page)}

List of plausible models performed with multi-model inference in $500 \mathrm{~m}$ buffer

List of plausible models performed with multi-model inference in $500 \mathrm{~m}$ buffer. The estimates are reported: the intercept (Int), the variables considered in each model (prm_500 = percentage of surface area occupied by permanent crops; spcs = species; und = undecomposed litter percentage), $\mathrm{R}^{2}, \mathrm{AIC}, \triangle \mathrm{AIC}$ and model weight (wi). In bold Relative Variable Importance values and significance 


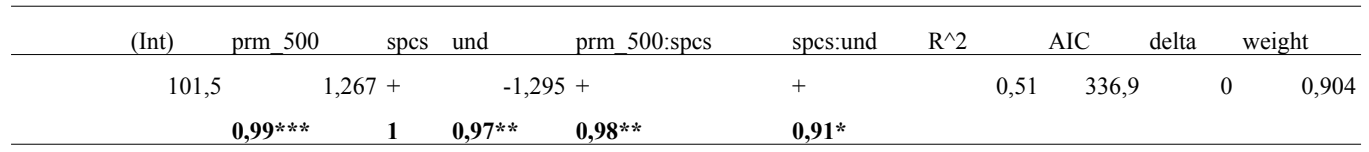

1 
Figure 1

Relation between population abundance, species and their interactions with environmental variables (a: permanent crops; b: undecomposed litter) .

Relation between population abundance, species and their interactions with environmental variables, calculated with the best fitting model chosen within Multi-model inference. (a) Permanent crops. (b) Undecomposed litter. Permanent crops = proportion of area covered by permanent crops (poplars, orchards) in buffer area of $250 \mathrm{~m}$ around the sampling plot; undecomposed litter $=$ mean percentage of undecomposed litter in the litter stratum. Confidence intervals (95\%) are also shown

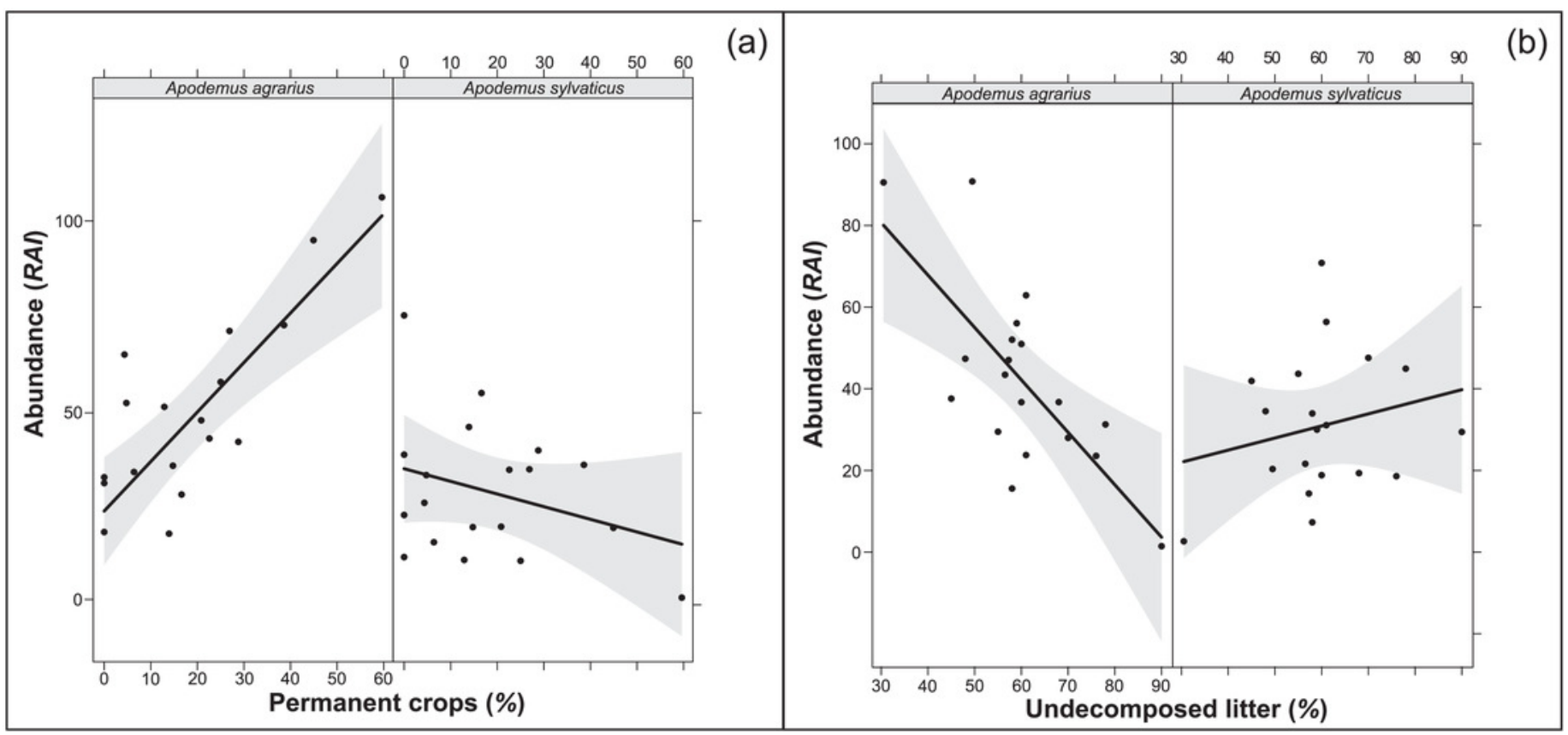

